\title{
Opioid Pharmacogenetics of Alcohol Addiction
}

\author{
Wade Berrettini \\ Karl E. Rickels Professor of Psychiatry, Center for Neurobiology and Behavior, Perelman School \\ of Medicine, University of Pennsylvania, Philadelphia, Pennsylvania, 19104 \\ Correspondence: wadeb@mail.med.upenn.edu
}

\begin{abstract}
Alcohol addiction is one of the most common and devastating diseases in the world. Given the tremendous heterogeneity of alcohol-addicted individuals, it is unlikely that one medication will help nearly all patients. Thus, there is a clear need to develop predictors of response to existing medications. Naltrexone is a $\mu$-opioid receptor antagonist, which has been approved in the United States for treatment of alcohol addiction since 1994. It has limited efficacy, in part because of noncompliance, but many patients do not respond despite high levels of compliance. There are reports that a missense single nucleotide polymorphism (rs179919 or A118G) in the $\mu$-opioid receptor gene predicts a favorable response to naltrexone if an individual carries a " $\mathrm{G}$ " allele. This work will review the evidence for this hypothesis. The data are promising that the " $\mathrm{G}$ " allele predisposes to a beneficial naltrexone response among alcohol-addicted persons, but additional research is needed to prove this hypothesis in prospective clinical trials.
\end{abstract}

V entral tegmental neurons release dopamine at nerve terminals in ventral striatum and medial prefrontal cortex. Activation of this circuit is a common element of abused drugs, including alcohol (e.g., Di Chiara and Imperato 1988; for review, see Koob and Volkow 2010). Thus, alcohol shares in common with nicotine, cocaine, amphetamine, morphine, etc, this property of enhancing dopamergic transmission in ventral striatum and medial prefrontal cortex. Both animal model and human studies are in agreement on this point (Boileau et al. 2003; Gilman et al. 2008; Spanagel 2009). This release of dopamine in the ventral striatum and medial prefrontal cortex is partially enhanced by stimulation of $\mu$-opioid receptors (for which endorphin is the primary ligand) located on inhibitory GABAergic interneurons in the ventral tegmen- tal area. The GABAergic interneurons inhibit the dopaminergic ventral tegmental neurons, whose activation signals reward. Thus, $\mu$-opioid receptor agonists enhance the likelihood of ventral tegmental dopaminergic neuron activation (and the experience of reward) by lessening the tonic inhibition of the associated GABAergic interneurons (Johnson and North 1992; Spanagel et al. 1992; Tanda and DiChiara 1998).

Given this circuitry, it has been consistently shown that endogenous opioids play a role in ethanol reinforcement in various animal paradigms. Endorphin elevations after alcohol are seen in discrete reward regions of the hypothalamus (Popp and Erickson 1998), ventral tegmentum, and ventral striatum (Rasmussen et al. 1998). It is important to note that endorphin deficient rats continue to self-administer

Editors: R. Christopher Pierce and Paul J. Kenny

Additional Perspectives on Addiction available at www.perspectivesinmedicine.org

Copyright (C) 2013 Cold Spring Harbor Laboratory Press; all rights reserved; doi: 10.1101/cshperspect.a012203

Cite this article as Cold Spring Harb Perspect Med 2013;3:a012203 
W. Berrettini

alcohol, indicating that endorphin is not the sole mechanism of alcohol reward (Grahame et al. 1998). The importance of $\mu$-opioid receptor activation as a mechanism for alcohol reward is underscored by the fact that alcohol consumption in alcohol-preferring rats is persistently reduced after inactivating $\mu$-opioid receptors in the ventral striatum (Myers and Robinson 1999). Similarly, decreased alcohol selfadministration is observed in primates after pretreatment with opioid antagonists (Altshuler et al. 1980). C57Bl/6J mice, an inbred strain that prefers alcohol, has increased endorphin release in the hypothalamus after alcohol administration (De Waele et al. 1992). Alcohol preferring rats have high levels of opioid gene mRNA species in the hypothalamus, prefrontal cortex, and mediodorsal nucleus of the thalamus (Marinelli et al. 2000), as well as increased $\mu$-opioid receptor density in the ventral striatum and medial prefrontal cortex.

\section{CLINICAL STUDIES OF NALTREXONE IN ALCOHOLISM}

The development of a substantial body of evidence, in the 1980s, that naltrexone (an orally active $\mu$-opioid receptor antagonist) diminished alcohol self-administration in animal models (Altshuler et al. 1980; Kiianmaa et al. 1983; Myers et al. 1986; Volpicelli et al. 1986) led to the first use of naltrexone in alcohol addicted populations in a controlled clinical trial (Volpicelli et al. 1992), the promising outcome of which was immediately confirmed in a second controlled clinical trial (O'Malley et al. 1992). Naltrexone was found to reduce alcohol craving and relapse to heavy drinking (operationally defined as five or more drinks / day for a man, four or more for a woman), but did not reduce abstinence rates. On the basis of these two controlled trials, naltrexone was approval by the FDA, in the absence of the usual pharmaceutical industry interest.

In the intervening 20 years, there have been more than 30 clinical trials of naltrexone in alcohol addiction (for review, see Bouza et al. 2004; Srisurapanont and Jarusuraisin 2005; Pettinati et al. 2006). Although the majority of these clinical trials show efficacy of naltrexone in reducing risk for relapse to heavy drinking, the effect size is small, with many patients having no benefit. This has resulted in multiple reports in which the naltrexone arm outcomes are not significantly better than the placebo arm outcomes (e.g., Krystal et al. 2001). This is an expected outcome, given the tremendous heterogeneity of clinical alcohol addiction. It is likely that important clinical characteristics, such as compliance, severity and duration of alcohol addiction, comorbidity (both medical and psychiatric), and/or attendance at psychosocial treatment, may influence outcomes.

In this situation, multiple investigators have attempted to define clinical characteristics, which might enhance the probability of naltrexone response. Some clinical measures have shown promise in characterizing a naltrexone responder: high alcohol craving (Chick et al. 2000; Monterosso et al. 2001; O’Malley et al. 2002) and strong family history of alcohol addiction (Monterosso et al. 2001), but family history of alcohol addiction did not predict response to naltrexone in the COMBINE multicenter trial (Capone et al. 2011). Alcohol addicts who experience greater euphoria after alcohol may have a better response to naltrexone (Volpicelli et al. 1995).

\section{A118G OPRM1 MISSENSE SINGLE NUCLEOTIDE POLYMORPHISM: MOLECULAR AND CELLULAR EFFECTS}

A common missense single nucleotide polymorphism (rs 1799971) in the first exon of the $\mu$ opioid receptor gene, OPRM1, was described by Bergen et al. (1997), A118G, or N40G, reflecting the fact that the A allele encodes asparagine, whereas the minor $\mathrm{G}$ allele encodes aspartate. The A (asparagine) allele is thought to be N-glycosylated (Huang et al. 2012), whereas this is not possible for the $\mathrm{G}$ (aspartate) allele, as there is no free amino group. Subsequent study (e.g., Gelernter et al. 1999; Szeto et al. 2001; Crowley et al. 2003; Tan et al. 2003) revealed large ethnic differences in allele frequencies (see Table 1).

This allele has been the subject of multiple molecular investigations to determine its 
Pharmacogenetics of Alcohol Addiction

Table 1. Frequency of G allele for A118G SNP in ethnic groups

\begin{tabular}{lccc}
\hline Ethnic group & Freq G & Ethnic group & Freq G \\
\hline African & $1 \%$ & Korean & $31 \%$ \\
African-American & $3 \%$ & Chinese & $35 \%$ \\
Swedish & $11 \%$ & Malaysian & $43 \%$ \\
European-American & $15 \%$ & Indian & $47 \%$ \\
\hline
\end{tabular}

functional consequences, in terms of gene expression, protein translation, receptor signaling, and receptor density. Initially, Bond et al. (1998) reported that the minor " $G$ " allele $\mu$-opioid receptor resulted in decreased affinity for binding to $\beta$-endorphin, compared to the common "A" allele receptor. There was no change in binding affinity for alkaloid ligands. This result has not been confirmed in subsequent investigations (Beyer et al. 2004; Ramchandani et al. 2010). In one such study transfected HEK293 cells (a fibroblastoid cell type) were used (Beyer et al. 2004), but the $118 \mathrm{G}$ allele did not differ in binding affinity for $\beta$-endorphin, compared to 118A. Beyer et al. (2004) also reported that the $118 \mathrm{G}$ allele was not different from the $118 \mathrm{~A}$ allele in rate of desensitization, internalization or resensitization, but $118 \mathrm{G}$ had decreased transcription, compared to 118A. Ramchandani et al. (2010) also did not report differences in kinetics of binding of $\beta$-endorphin to the 118G, compared to 118A. Mahmoud et al. (2011), using a whole cell patch clamp technique in acutely dissociated trigeminal ganglion neurons, reported that morphine was fivefold less active at the " $G$ " allele receptor form in activating a $\mathrm{Ca}^{2+}$ channel. There was no such difference for fentanyl. Zhang et al. (2005) conducted allelic imbalance studies in postmortem human brain, revealing a marked decrease in 118G allele mRNA (see Fig. 1). In a second experiment, they showed in vitro evidence of a marked decreased translation of the 118G mRNA (see figures in Ramchandani et al. 2010) (Zhang et al. 2005).

\section{A118G OPRM1 MISSENSE SINGLE NUCLEOTIDE POLYMORPHISM: ANIMAL MODEL STUDIES}

In the murine OPRM1 gene, there is no equivalent of the A118G naturally occurring variation. A homologous variation (A112G, with the A allele encoding asparagines and the $\mathrm{G}$ allele encoding aspartate, as in the human OPRM1 gene) was created by bacterial artificial chromosome engineering and murine transgenic techniques by Mague et al. (2009). They reported decreased transcription and translation of the $\mathrm{G}$ allele in transgenic C57Bl/6 mouse brain (see Fig. 2, a result congruous with the human postmortem brain ex vivo results of Zhang et al. 2005), as well as the in vitro results of Beyer et al. (2004). There was a blunted locomotor response to morphine in the $112 \mathrm{G}$ mice, as well as decreased morphine
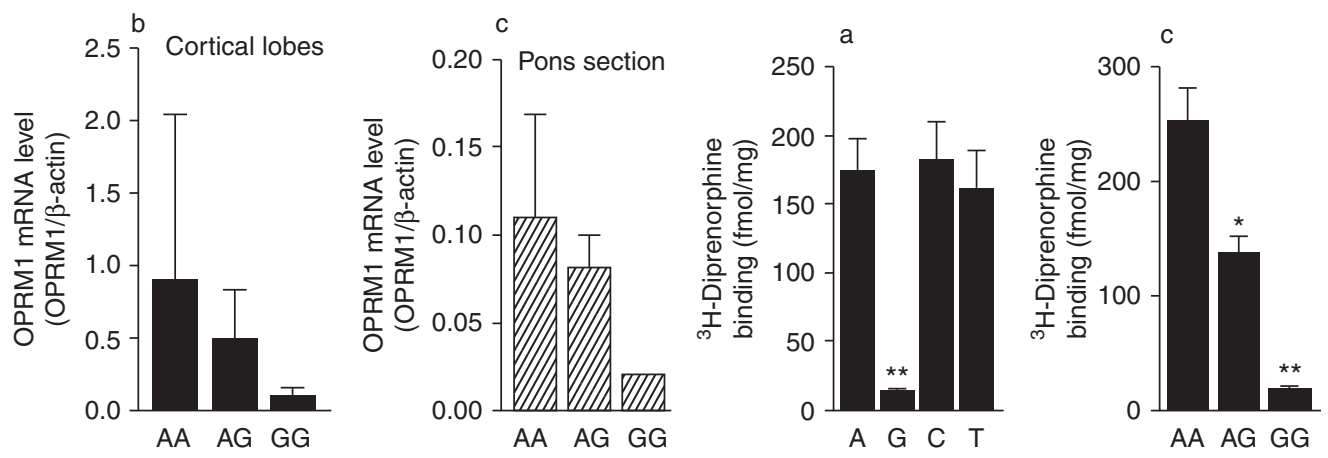

Figure 1. Transcriptional and translational efficiency of the $118 \mathrm{G}$ allele is markedly limited, compared to the A allele. Allelic imbalance was shown in the human postmortem brain, with the $118 \mathrm{G}$ showing marked transcriptional decrease. Translation of the $118 \mathrm{G}$ was also decreased using an in vitro approach. ${ }^{*} p<0.05 ;{ }^{* *} p<0.01$. (Created from data by Zhang et al. 2005.) 
W. Berrettini
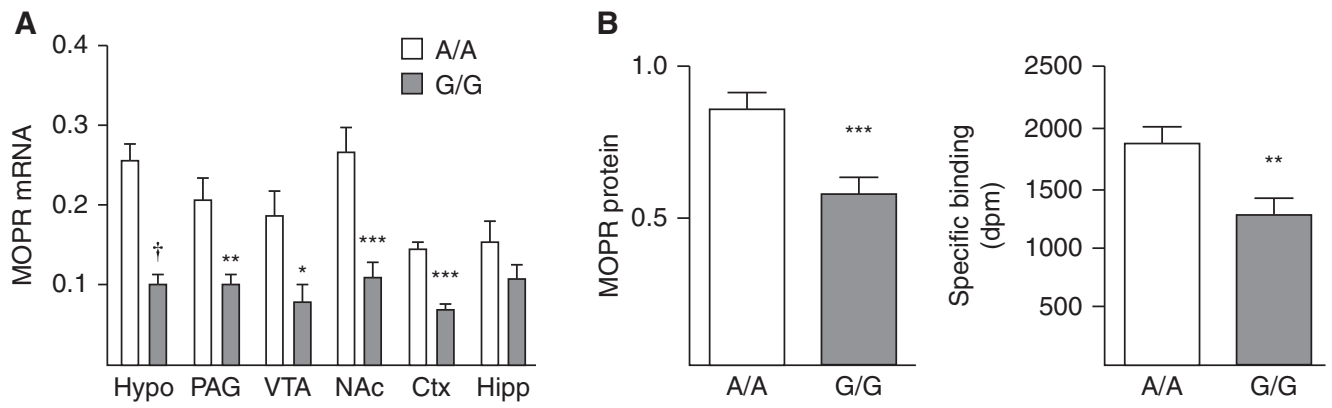

Figure 2. A mouse homolog of the $118 \mathrm{G}$ allele also shows decreased transcriptional and translational efficiency. A C57B/6J BAC was subject to site-directed mutagenesis to create a A112G variant, homologous to the human A118G. LoxP-mediated homologous recombination was used with the BAC to create C57BI/6J with this variant. As with the human postmortem brain studies of A118G, the $\mathrm{G}$ allele in the mouse brain reduces transcription and translation. ${ }^{*} p<0.05$; ${ }^{* *} p<0.01$; ${ }^{* * *} p<0.001 ; \dagger<0.0001$. (From Mague et al. 2009; reprinted, with permission, from the National Academy of Sciences (C) 2009.)

conditioned place preference $(\mathrm{CPP})$ in $112 \mathrm{G}$ female mice, the latter being a sexually dimorphic response, with $112 \mathrm{G}$ males showing the expected $\mathrm{CPP}$ response to morphine.

Two other forms of transgenic mice were produced, using homologous recombination to replace the murine OPRM1 exon 1 with one of the two forms (118A and 118G) of human OPRM1 exon 1 (Ramchandani et al. 2010). These investigators conducted in vivo microdialysis experiments in the ventral striatum, demonstrating that the $118 \mathrm{G}$ mice had the expected elevations in dopamine release after alcohol, whereas the 118A mice had no significant increase over baseline (see AA and AG group figures in Ramchandani et al. 2011). These data suggest that the "G" allele conveys an increased rewarding valence to alcohol, compared to the "A" allele.

There have been several studies of a similar SNP in the rhesus monkey, the C77G, which results in a homologous amino acid change, asparagine to aspartate (Fig. 3) (Barr et al. 2007, 2010; Vallender et al. 2010). Both groups report that the $\mathrm{G}$ allele monkeys consume significantly more alcohol than the CC monkeys. Further, both groups note that naltrexone significantly decreases alcohol intake in the GG monkeys.

These reports, taken together, are consistent with the hypothesis that the $118 \mathrm{G}$ allele (or its equivalent in mouse and primate) conveys a greater rewarding effect of alcohol, a difference that is inhibited by naltrexone. These studies are remarkably consistent, given the species, paradigm, technical, and molecular engineering differences among these studies.

\section{A118G OPRM1 MISSENSE SINGLE NUCLEOTIDE POLYMORPHISM: HUMAN PHARMACOGENETIC STUDIES OF ALCOHOL}

There have been several pharmacogenetic reports of the A118G SNP in human laboratory

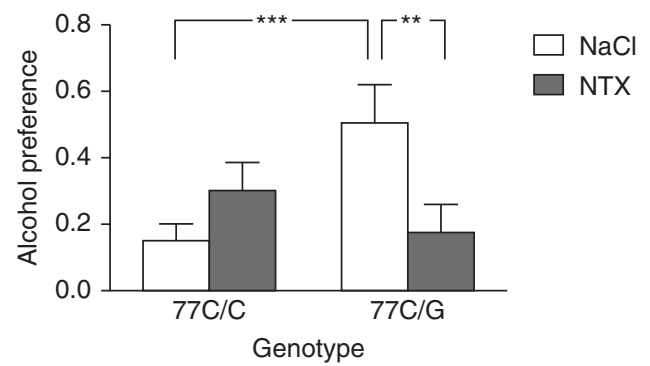

Figure 3. The rhesus homolog of the $118 \mathrm{G}, 77 \mathrm{G}$, is associated with increased alcohol consumption, which is attenuated by naltrexone treatment. Monkeys were given access to an ethanol solution or vehicle in daily 1 -h sessions. Genotype $\times$ treatment interaction predicted the effect of naltrexone (NTX) on ethanol preference. ${ }^{* *} p<0.01{ }^{* * *} p<0.001$. (From Barr et al. 2010; reprinted, with permission, from Elsevier (C) 2010.) 
experiments involving alcohol (Ray and Hutchison 2004, 2007; Ramchandani et al. 2010; Ray et al. 2010; Setiawan et al. 2011). In a laboratory investigation of the A118G pharmacogenetics of alcohol reward, Ray and Hutchison (2004, 2007) showed that the $G$ allele carriers experienced significantly greater euphoria after standard oral doses of alcohol (while controlling for breath alcohol concentration), compared to AA persons. Further, naltrexone significantly blunted the euphoria in the $G$ allele carriers and was without effect in the AA group (see Fig. 4).

In agreement with this result, Ramchandani reported that $\mathrm{G}$ allele carriers had a greater striatal release of dopamine after alcohol (using a raclopride $\mathrm{PET}$ scan technique), compared to AA participants (see Ramchandani et al. 2011). In a more naturalistic approach, Ray et al. (2010) studied drinking habits of social drinkers over a 5-d period, analyzing subjective responses to alcohol by A118G genotype. G allele carriers reported more significantly more "vigor" less negative mood after drinking, compared to the AA group. Similarly, Setiawan et al. (2011) studied the subjective response to alcohol in social drinkers after a dose of naltrexone. Naltrexone significantly decreased the ethanol-induced "euphoria" to a priming dose of alcohol in subjects with the $\mathrm{G}$ allele, compared to AA participants.

Taken together, these human laboratory studies of the A118G variant on effect of alcohol are remarkably consistent, with the clear conclusion that the $\mathrm{G}$ allele permits people to experience alcohol in a more rewarding manner, compared to AA individuals. It is also notable that naltrexone is able to blunt this euphoria in $\mathrm{G}$ allele carriers, but not in AA persons. This latter observation is consistent with subjective reports of the effect of naltrexone in clinical trials for alcohol addiction, in which the medication attenuated alcohol-induced euphoria among responders (Volpicelli et al. 1995).

\section{PHARMACOGENETIC STUDIES OF NALTREXONE CLINICAL TRIALS FOR ALCOHOL ADDICTION}

There have been multiple pharmacogenetic studies of naltrexone clinical trials for alcohol addiction published in the last decade. The first such publication (Oslin et al. 2003) was a

\section{A}

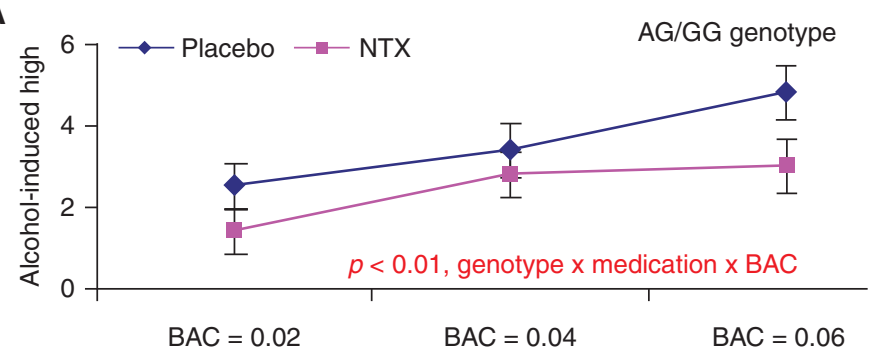

B

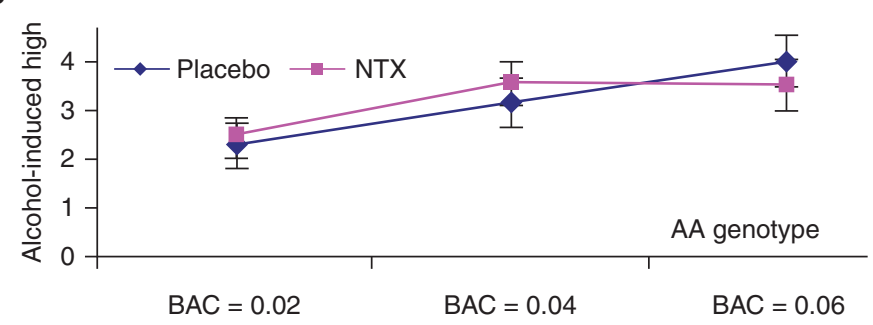

Figure 4. (A) 118G allele carriers have a greater euphoria response to alcohol, compared to homozygous A persons; $(B)$ naltrexone blunts the alcohol-induced euphoria for $118 \mathrm{G}$ carriers, but has no such effect in persons who are homozygous A. (Created from data by Ray and Hutchinson 2007.) 
W. Berrettini

retrospective analysis of three naltrexone trials of similar design, two conducted at the University of Pennsylvania and one at the University of Connecticut. Compliance was monitored by riboflavin testing and by pill counts. Eighty-two patients ( 71 of European descent) who were randomized to naltrexone and 59 randomized to placebo (all of European descent) in one of three randomized placebo-controlled clinical trials of naltrexone were genotyped at the $\mathrm{A}_{+118} \mathrm{G}$ (Asn40Asp) and $\mathrm{C}_{+17} \mathrm{~T}$ (Ala6Val) SNPs in the $\mu$-opioid gene (OPRM1). The association between genotype and drinking outcomes was measured over 12 wk of treatment. For purposes of examining the pharmacogenetics of naltrexone response, the analysis was limited to those subjects with well-defined outcome data who had at minimum 6-wk exposure to the medication. The primary drinking outcome considered was relapse to heavy drinking ( $\geq 5$ drinks in a single day for men or $\geq 4$ drinks for women). This definition of heavy drinking was the primary outcome for each of the trials. The time line follow back method was employed (along with self report) to measure alcohol consumption (Sobell and Sobell 1992). There was a significantly greater proportion of naltrexone treated subjects with the G allele variant who did not return to heavy drinking (no relapse) compared to those with those homozygous for the A allele (Wald $=4.04,1 \mathrm{df}, \mathrm{OR}=3.47$ [95\% CI: 1.0311.67], $p=0.045$; see Table 2).

This finding was confirmed in a larger multisite study of naltrexone, acamprosate, and placebo for alcohol addiction (Anton et al. 2008). Alcohol addicted subjects were treated for $16 \mathrm{wk}$ with $100 \mathrm{mg}$ of naltrexone. All participants received medical management alone or with combined behavioral intervention.
When considering only those patients receiving medical management alone, there was an significant effect of naltrexone on "good outcome" among the $118 \mathrm{G}$ carriers, whereas there was no such effect for the patients receiving naltrexone who were homozygous A118 (see Table 2). However, there was no such effect in the naltrexone group receiving medical management with combined behavioral intervention. The combined behavioral intervention was delivered by licensed behavioral health specialists in up to 20 flexible participant need-adjusted 50-min sessions. Combined behavioral intervention, an intensive and specific alcohol intervention, may have compensated for the placebo effect, thereby suppressing the chances of observing a main effect of naltrexone or a genetic interaction. The data presented by Anton et al. (2008) are consistent with this thinking. A gene $\mathrm{X}$ medication interaction may be observable only in patients who can show obvious benefit from the medication over placebo.

In a small Korean study of naltrexone in alcohol addiction (Kim et al. 2010), subjects adherent to naltrexone treatment with one or two copies of the Asp40 allele took a significantly longer time than the Asn40 group to relapse to heavy drinking $(p=0.014)$. Although not significant, the Asn40 group treated with naltrexone had a 10.6 times greater relapse rate than the Asp40 variant group. There was no effect on abstinence.

In the Veterans Administration multisite study of naltrexone in alcohol addiction, Gelernter et al. (2007) reported that the 118G allele did not predict outcome among 149 participants in the naltrexone group and 64 in the placebo group. There are several possible explanations for this result. First, the efficacy of

Table 2. A118G genotype and good outcome in naltrexone studies of pharmacotherapy for alcohol addiction

\begin{tabular}{|c|c|c|c|c|}
\hline \multirow[b]{2}{*}{ Genotype at A118G } & \multicolumn{2}{|c|}{ Oslin et al. 2003} & \multicolumn{2}{|c|}{ Anton et al. 2008} \\
\hline & Naltrexone & Placebo & Naltrexone & Placebo \\
\hline G allele carriers & $85 \%^{\mathrm{a}}$ & $55 \%$ & $89 \%^{\mathrm{b}}$ & $54 \%$ \\
\hline Homozygous A & $56 \%$ & $46 \%$ & $56 \%$ & $50 \%$ \\
\hline
\end{tabular}

${ }^{\mathrm{a}} P=0.04$, odds ratio $=3.5$.

${ }^{\mathrm{b}} P=0.005$, genotype $\times$ medication interaction; odds ratio $=5.8$. 
Pharmacogenetics of Alcohol Addiction

naltrexone is certainly influenced by compliance, and the compliant population was defined as those who opened the medication bottle a minimum of $50 \%$ of the time, so that medication compliance was defined liberally. Second, it is likely that high levels of comorbidity influence response to naltrexone. The study population had substantial rates of recurrent unipolar illness, antisocial personality and anxiety disorders, and had severe alcohol addiction of long duration. These factors might overwhelm any genetic predisposition to respond to naltrexone. Third, the study had limited power; for example, there were only nine $118 \mathrm{G}$ carriers in the placebo group.

Coller et al. (2011) recently reported the results of a naltrexone and cognitive-behavioral therapy trial in 100 Australian alcohol addicted persons. They reported an overall effect of naltrexone on relapse to heavy drinking, but no influence of the A188G variants. The absence of a control group makes this study less ideal, as does the small sample size, with 68 study completers.

Taken together, the A118G clinical trials in naltrexone treatment for alcohol addiction remain promising, but there are clear unanswered question, including the influence of counseling, compliance, and comorbidity on outcome. Available depot formulations of naltrexone may reduce noncompliance, but the influence of comorbidity and counseling may be more difficult to resolve. It will be necessary to conduct pharmacogenetic alcohol addiction naltrexone trials, for which participants are randomized by A118G genotype into the naltrexone or placebo arm to reduce possible sources of bias. These trials should be characterized by:

1. large size (at least $\sim 150$ persons per arm, including oversampling of $\mathrm{G}$ allele carriers) to ensure adequate power;

2. rigorous assessment of compliance;

3. randomization stratified by genotype;

4. careful assessment of comorbidity; and

5. modest psychotherapeutic intervention, so as to mirror "real world" clinical practice.

\section{SUMMARY}

There are extensive data, across species, to suggest that the $118 \mathrm{G}$ form of the $\mu$-opioid receptor is characterized by decreased transcription and translation. There are convincing data, from murine, primate, and human laboratory studies, that the 118G (or its species-specific homolog) variant permits alcohol to have a greater rewarding valence, leading to increased alcohol consumption. Further, the human and rhesus data are equally convincing that naltrexone is able to blunt this greater rewarding signal. Last, the possibility that A118G alleles can be used clinically to identify alcohol addicted persons with a greater probability to have a beneficial response to naltrexone is a hypothesis that deserves testing on a large scale, with the characteristics noted above.

\section{REFERENCES}

Altshuler HL, Phillips PA, Feinhandler DA. 1980. Alteration of ethanol self-administration by naltrexone. Life Sci 26: 679-688.

Anton R, O’Malley OG, Couper D, Swift R, Pettinati H, Goldman D. 2008. $\mu$-opioid receptor Asn40Asp predicts naltrexone response. Arch Gen Psychiatry 65: 135-144.

Barr CS, Schwandt M, Lindell SG, Chen SA, Goldman D, Suomi SJ, Higley JD, Heilig M. 2007. Association of a functional polymorphism in the $\mu$-opioid receptor gene with alcohol response and consumption in male rhesus macaques. Arch Gen Psychiatry 64: 369-376.

Barr CS, Chen SA, Schwandt ML, Lindell SG, Sun H, Suomi SJ, Heilig M. 2010. Suppression of alcohol preference by Naltrexone in the rhesus macaque: A critical role of genetic variation at the $\mu$-opioid receptor gene locus. Biol Psychiatry 67: 78-80.

Bergen AW, Kokoszka J, Peterson R, et al. 1997. $\mu$-opioid receptor gene variants: Lack of association with alcohol dependence. Mol Psychiatry 2: 490-494.

Beyer A, Koch T, Schröder H, Schulz S, Höllt V. 2004. Effect of the A118G polymorphism on binding affinity, potency and agonist-mediated endocytosis, desensitization, and resensitization of the human $\mu$-opioid receptor. J Neurochem 89: 553-560.

Boileau I, Assad JM, Pihl JO, Benkelfat C, Leyton M, Diksic M, Tremblay ME, Dagher A. 2003. Alcohol promotes dopamine release in the human nucleus accumbens. Synapse 49: 226-231.

Bond C, LaForge KS, Tian M, Melia D, Zhang S, Borg L, Gong J, Schluger J, Strong JA, Leal SM, et al. 1998. Singlenucleotide polymorphism in the human $\mu$-opioid receptor gene alters $\beta$-endorphin binding and activity: Possible implications for opiate addiction. Proc Natl Acad Sci 95: 9608-9613. 
W. Berrettini

Bouza C, Angeles M, Muñoz A, Amate JM. 2004. Efficacy and safety of naltrexone and acamprosate in the treatment of alcohol dependence: A systematic review. Addiction 99: 811-828.

Capone C, Kahler CW, Swift RM, O’Malley SS. 2011. Does family history of alcoholism moderate naltrexone's effects on alcohol use? J Stud Alcohol Drugs 72: 135-140.

Chick J, Anton R, Checinski K, Croop R, Drummond DC, Farmer R, Labriola D, Marshall J, Moncrieff J, Morgan MY, et al. 2000. A multicenter double-blind randomized trial of naltrexone in the treatment of alcoho dependence or abuse. Alcohol Alcoholism 35: 587-593.

Coller JK, Cahill S, Edmonds C, Farquharson AL, Longo M, Minniti R, Sullivan T, Somogyi AA, Whilte JM. 2011. OPRM1 A118G genotype fails to predict the effectiveness of naltrexone treatment for alcohol dependence. Pharmacogenet Genomics 21: 902-905.

Crowley JJ, Oslin DW, Patkar AA, Gottheil E, DeMaria PA Jr, O’Brien CP, Berrettini WH, Grice DE. 2003. A genetic association study of the $\mu$-opioid receptor and severe opioid dependence. Psychiatr Genet 13: 169-173.

De Waele JP, Papachristou DN, Gianoulakis C. 1992. The alcohol-preferring $\mathrm{C} 57 \mathrm{BL} / 6$ mice present an enhanced sensitivity of the hypothalamic $\beta$-endorphin system to ethanol than the alcohol-avoiding DBA/2 mice. J Pharmacol Exp Ther 261: 788-794.

Di Chiara G, Imperato A. 1988. Drugs abused by humans preferentially increase synaptic dopamine concentrations in the mesolimbic system of freely moving rats. Proc Natl Acad Sci 85: 5274-5278.

Gelernter J, Kranzler H, Cubells J. 1999. Genetics of two m opioid receptor gene (OPRM1) exon I polymorphisms: Population studies, and allele frequencies in alcohol- and drug-dependent subjects. Mol Psychiatry 4: 476-483.

Gelernter J, Gueorguieva R, Kranzler HR, et al. 2007. Opioid receptor gene (OPRM1, OPRK1, and OPRD1) variants and response to naltrexone treatment for alcohol dependence: Results from the VA Cooperative Study. Alcohol Clin Exp Res 31: 555-563.

Gilman JM, Ramchandani VA, Davis MB, Bjork JM, Hommer DW. 2008. Why we like to drink: A functional magnetic resonance imaging study of the rewarding and anxiolytic effects of alcohol. J Neurosci 28: 4583-4591.

Grahame NJ, Low MJ, Cunningham CL. 1998. Intravenous self-administration of ethanol in $\beta$-endorphin-deficient mice. Alcohol Clin Exp Res 22: 1093-1098.

Huang P, Chen C, Mague SD, Blendy JA, Liu-Chen LY. 2012. A common single nucleotide polymorphism A118G of the $\mu$-opioid receptor alters its N-glycosylation and protein stability. Biochem J 441: 379-386.

Johnson SW, North RA. 1992. Opioids excite dopamine neurons by hyperpolarization of local interneurons. J Neurosci 12: 483-488.

Kiianmaa K, Hoffman PL, Tabakoff B. 1983. Antagonism of the behavioral effects of ethanol by naltrexone in BALB/c, C57BL/6, and DBA/2 mice. Psychopharmacology (Berl) 79: 291-294.

Kim SG, Kim CM, Choi SW, Jae YM, Lee HG, Son BK, Kim JG, Choi YS, Kim HO, Kim SY, et al. 2009. A $\mu$ opioid receptor gene polymorphism (A118G) and naltrexone treatment response in adherent Korean alcohol- dependent patients. Psychopharmacology (Berl) 201:611618.

Koob GF, Volkow ND. 2010. Neurocircuitry of addiction. Neuropsychopharmacology 35: 217-238.

Krystal JH, Cramer JA, Krol WF, Kirk GF, Rosenheck RA. 2001. Naltrexone in the treatment of alcohol dependence. N Engl J Med 345: 1734-1739.

Mague SD, Isiegas C, Huang P, Liu-Chen LY, Lerman C, Blendy JA. 2009. Mouse model of OPRM1 (A118G) polymorphism has sex-specific effects on drug-mediated behavior. Proc Natl Acad Sci 106: 10847-10852.

Mahmoud S, Thorsell A, Sommer WH, Heilig M, Holgate JK, Bartlett SE, Ruiz-Velasco V. 2011. Pharmacological consequence of the A118G $\mu$ opioid receptor polymorphism on morphine- and fentanyl-mediated modulation of $\mathrm{Ca}^{2+}$ channels in humanized mouse sensory neurons. Anesthesiology 115: 1054-1062.

Marinelli PW, Kiianmaa K, Gianoulakis C. 2000. Opioid propeptide mRNA content and receptor density in the brains of AA and ANA rats. Life Sci 66: 1915-1927.

Monterosso JR, Flannery BA, Pettinati HM, et al. 2001. Predicting treatment response to naltrexone: The influence of craving and family history. Am J Addict 10: 258-268.

Myers RD, Robinson DE. 1999. $\mu$ and D2 receptor antisense oligonucleotides injected in nucleus accumbens suppress high alcohol intake in genetic drinking HEP rats. Alcohol 18: $225-233$.

Myers RD, Borg S, Mossberg R. 1986. Antagonism by naltrexone of voluntary alcohol selection in the chronically drinking macaque monkey. Alcohol 3: 383-388.

O'Malley SS, Jaffe AJ, Chang G, Schottenfeld RS, Meyer RE, Rounsaville B. 1992. Naltrexone and coping skills therapy for alcohol dependence: A controlled study. Arch Gen Psychiat 49: 881-887.

Oslin DW, Berrettini W, Kranzler HR, et al. 2003. A functional polymorphism of the $\mu$-opioid receptor gene is associated with naltrexone response in alcohol-dependent patients. Neuropsychopharmacology 28: 1546-1552.

Pettinati HM, O’Brien CP, Rabinowitz AR, Wortman SP, Oslin DW, Kampman KM, Dackis CA. 2006. The status of naltrexone in the treatment of alcohol dependence: Specific effects on heavy drinking. J Clin Psychopharmacol 26: 610-625.

Popp RL, Erickson CK. 1998. The effect of an acute ethanol exposure on the rat brain POMC opiopeptide system. Alcohol 16: 139-148.

Ramchandani VA, Umhau J, Pavon FJ, Ruiz-Valasco V, Margas W, Sun H, Damadzic R, Eskay R, Schoor M, Thorsell A, et al. 2010. A genetic determinant of the striatal dopamine response to alcohol in men. Mol Psychiatry 16: 809-817.

Ramchandani VA, Umhau J, Pavon FJ, Ruiz-Velasco V, Margas W, Sun H, Damadzic R, Eskay R, Schoor M, Thorsell A, et al. 2011. A genetic determinant of the striatal dopamine response to alcohol in men. Mol Psychiatry 16: 809-817.

Rasmussen DD, Bryant CA, Boldt BM, Colasurdo EA, Levin N, Wilkinson CW. 1998. Acute alcohol effects on opiomelanocortinergic regulation. Alcohol Clin Exp Res 22: $789-801$. 
Ray LA, Hutchison KE. 2004. A polymorphism of the $\mu$ opioid receptor gene (OPRM1) and sensitivity to the effects of alcohol in humans. Alcohol Clin Exp Res 28: $1789-1795$.

Ray LA, Hutchison KE. 2007. Effects of naltrexone on alcohol sensitivity and genetic moderators of medication response: A double-blind placebo-controlled study. Arch Gen Psychiatry 64: 1069-1077.

Ray LA, Miranda R Jr, Tidey JW, McGeary JE, MacKillop J, Gwaltney CJ, Rohsenow DJ, Swift RM, Monti PM. 2010. Polymorphisms of the $\mu$-opioid receptor and dopamine D4 receptor genes and subjective responses to alcohol in the natural environment. J Abnorm Psychol 119: 115-125.

Setiawan E, Pihl RO, Cox SM, Gianoulakis C, Palmour RM, Benkelfat C, Leyton M. 2011. The effect of naltrexone on alcohol's stimulant properties and self-administration behavior in social drinkers: Influence of gender and genotype. Alcohol Clin Ex Res 35: 1134-1141.

Sobell LC, Sobell MB. 1992. Timeline follow-back: A technique for assessing self-reported alcohol consumption. In Measuring alcohol consumption (ed. Litten R, Allen J), pp. 41-65. Humana, Totowa, NJ.

Spanagel R. 2009. Alcoholism: A systems approach from molecular physiology to addictive behavior. Physiol Rev 89: 649-705.

Spanagel R, Herz A, Shippenberg TS. 1992. Opposing tonically active endogenous opioid systems modulate the mesolimbic dopaminergic pathway. Proc Natl Acad Sci 89: 2046-2050.
Srisurapanont M, Jarusuraisin N. 2005. Naltrexone for the treatment of alcoholism: A meta-analysis of randomized controlled trials. Int J Neuropsychopharmacol 8: 267-280.

Szeto CY, Tang NL, Lee DT, Stadlin A. 2001. Association between $\mu$ opioid receptor gene polymorphisms and Chinese heroin addicts. Neuroreport 12: 1103-1106.

Tan EC, Tan CH, Karupathivan U, Yap EP. 2003. $\mu$ opioid receptor gene polymorphisms and heroin dependence in Asian populations. Neuroreport 14: 569-572.

Tanda GL, Di Chiara G. 1998. A dopamine $\mu$ (1) opioid link in the rat ventral tegmentum shared by palatable food (Fonzies) and non-psychostimulant drugs of abuse. Eur J Neurosci 10: 1179-1187.

Vallender EJ, Ruedi-Bettschen D, Miller GM, Platt DM. 2010. A pharmacogenetic model of naltrexone-induced attenuation of alcohol consumption in rhesus monkeys. Drug Alcohol Depend 109: 252-256.

Volpicelli JR, Davis MA, Olgin JE. 1986. Naltrexone blocks the post-shock increase of ethanol consumption. Life Sci 38: $841-847$.

Volpicelli JR, Alterman AI, Hayashida M, O’Brien CP. 1992. Naltrexone in the treatment of alcohol dependence. Arch Gen Psychiatry 49: 876-880.

Volpicelli JR, Watson NT, King AC, Sherman CE, O'Brien CP. 1995. Effect of naltrexone on alcohol "high" in alcoholics. Am J Psychiat 152: 613-615.

Zhang Y, Wang DX, Johnson AD, Papp AC, Sadee W. 2005. Allelic expression imbalance of human $\mu$-opioid receptor (OPRM1) caused by variant A118G. J Biol Chem 280: $32618-32624$ 


\title{
$\&_{\mathrm{CSH}}^{\infty} \&$ Cold Spring Harbor \\ $\stackrel{\text { PERSPECTTMES }}{\longrightarrow \infty_{\infty}}$ Perspectives in Medicine
}

\section{Opioid Pharmacogenetics of Alcohol Addiction}

\author{
Wade Berrettini
}

Cold Spring Harb Perspect Med 2013; doi: 10.1101/cshperspect.a012203 originally published online May 31,2013

\section{Subject Collection Addiction}

Developments from Bulk Optogenetics to Single-Cell Strategies to Dissect the Neural Circuits that Underlie Aberrant Motivational States Jose Rodriguez-Romaguera, Vijay M.K. Namboodiri, Marcus L. Basiri, et al.

Consequences of Parental Opioid Exposure on Neurophysiology, Behavior, and Health in the Next Generations

Fair M. Vassoler and Mathieu E. Wimmer

Animal Models of the Behavioral Symptoms of Substance Use Disorders Louk J.M.J. Vanderschuren and Serge H. Ahmed

Translational Research in Nicotine Addiction Miranda L. Fisher, James R. Pauly, Brett Froeliger, et al.

Neonatal Opioid Withdrawal Syndrome (NOWS): A Transgenerational Echo of the Opioid Crisis Andrew E. Weller, Richard C. Crist, Benjamin C. Reiner, et al.

Impairment of Synaptic Plasticity by Cannabis, $\Delta^{\mathbf{9}}$ -THC, and Synthetic Cannabinoids Alexander F. Hoffman, Eun-Kyung Hwang and Carl R. Lupica

Drug-Evoked Synaptic Plasticity of Excitatory Transmission in the Ventral Tegmental Area Camilla Bellone, Michael Loureiro and Christian Lüscher

Opioid-Induced Molecular and Cellular Plasticity of Ventral Tegmental Area Dopamine Neurons Marie A. Doyle and Michelle S. Mazei-Robison
The Persistent Challenge of Developing Addiction Pharmacotherapies

Sarah E. Swinford-Jackson, Charles P. O'Brien,

Paul J. Kenny, et al.

Opioid Modulation of the Gut-Brain Axis in Opioid-Associated Comorbidities

Li Zhang and Sabita Roy

Epigenetics of Drug Addiction Andrew F. Stewart, Sasha L. Fulton and lan Maze

Genetic Vulnerability to Opioid Addiction Brian Reed and Mary Jeanne Kreek

Glutamatergic Systems and Memory Mechanisms

Underlying Opioid Addiction Jasper A. Heinsbroek, Taco J. De Vries and Jamie Peters

Mechanisms of Nicotine Addiction Marina R. Picciotto and Paul J. Kenny

Neural Substrates and Circuits of Drug Addiction Matthew W. Feltenstein, Ronald E. See and Rita A. Fuchs

The Role of the Central Amygdala in Alcohol Dependence Marisa Roberto, Dean Kirson and Sophia Khom

For additional articles in this collection, see http://perspectivesinmedicine.cshlp.org/cgi/collection/ 